\title{
Clostridium schirmacherense sp. nov., an obligately anaerobic, proteolytic, psychrophilic bacterium isolated from lake sediment of Schirmacher Oasis, Antarctica
}

\author{
Syed Imteyaz Alam, ${ }^{1}$ Aparna Dixit, ${ }^{1}$ G. S. N. Reddy, ${ }^{2}$ S. Dube, ${ }^{3}$ \\ Meehir Palit, ${ }^{4}$ S. Shivaji ${ }^{3}$ and Lokendra Singh ${ }^{1}$ \\ ${ }^{1,4}$ Biotechnology Division ${ }^{1}$ and Vertox Laboratory ${ }^{4}$, Defence Research and Development \\ Establishment, Gwalior - 474002, India \\ ${ }^{2}$ School of Life Sciences, Arizona State University, Tempe, AZ 85287, USA \\ ${ }^{3}$ Centre for Cellular and Molecular Biology, Uppal Road, Hyderabad - 500007, India
}

Correspondence Lokendra Singh Ist2397@rediffmail.com
Prokaryotes dominate Antarctic ecosystems and play major roles in food chains, biogeochemical cycles and the mineralization of pollutants. Recent investigations using modern molecular biological techniques as well as classical procedures have demonstrated that many of the Antarctic microorganisms reported to date represent novel species and exhibit broad phylogenetic diversity, since they include representatives from both the Archaea and the Bacteria (Alam et al., 2003; Johnson \& Bellinoff, 1981; Johnson et al., 1981; Madden et al., 1979; Miller \& Leschine, 1984; Shivaji et al., 1989, 1992).

Published online ahead of print on 18 November 2005 as DOI 10.1099/ijs.0.63808-0.

The GenBank/EMBL/DDBJ accession number for the 16S rRNA gene sequence of strain $\mathrm{AP}^{\mathrm{T}} 5^{\mathrm{T}}$ is $\mathrm{AM} 114453$.

Details of glucose fermentation and amino acid fermentation by strain $\mathrm{AP} 15^{\top}$ are available as supplementary tables in IJSEM Online.
Despite the extreme climatic conditions that persist in Antarctica, micro-organisms have been detected in all of the continent's distinctive habitats, e.g. lakes, ponds, rivers, streams, rocks and soil. These habitats differ from one another with respect to nutrients, temperature range, water activity and other physico-chemical parameters. Since these factors influence the survival and growth of microorganisms, the microbial flora are bound to vary from one habitat to the other. Free water is available only during the summer, in oases that experience seasonal variation during late autumn and spring. The biology of these freshwater oases is therefore likely to be different from that of the rest of the continent. Microbiological studies in specific regions of continental Antarctica have been largely directed towards the isolation and characterization of psychrophilic microorganisms. The number of newly isolated anaerobes has increased over the past few years, the main emphasis being on their morphological/physiological characterization and 
phylogenetic analysis (Dixit et al., 2005; Attwood et al., 1996; Broda et al., 2000a, b; Engle et al., 1996; Toda et al., 1988). Anaerobic microbial communities and micro-organisms have been described by various workers during investigations of the Antarctic ecosystem (Franzmann et al., 1991; Franzmann \& Rohde, 1991; Franzmann \& Dobson, 1992; Mountfort et al., 1997). Proteolytic bacteria play a crucial role in food chains and in the aquatic ecosystems of lakes and other bodies of water in Antarctica, including dry valleys, coastal lakes and the McMurdo Ice Shelf. These investigations have provided clues as to the photosynthesis and carbon flux associated with benthic cyanobacterial mats.

Cold-active anaerobic bacteria, which produce extracellular proteases, potentially can be utilized for the biodegradation of organic wastes that are rich in protein, e.g. night-soil (human faeces), in low-temperature areas, as the hydrolysis of biopolymers is the first step in the anaerobic digestion process. These extracellular proteases from psychrophilic anaerobes might possess unique adaptive and structural features not present in those from other aerobic, mesophilic or thermophilic microbes. In this communication, we describe the characterization of an anaerobic proteolytic bacterium from Antarctic lake sediment. On the basis of the phenotypic and genotypic data, we conclude that $\mathrm{AP} 15^{\mathrm{T}}$ represents a novel species.

Strain $\mathrm{AP}^{\mathrm{T}} 5^{\mathrm{T}}$ was isolated from a lake-sediment sample collected from Schirmacher Oasis (Antarctica) between 20 January and 20 February 1994 during the 14th Indian Summer Scientific Expedition. The geographical coordinates of the site are $70^{\circ} 45^{\prime} 12^{\prime \prime} \mathrm{S}$ and $11^{\circ} 46^{\prime} \mathrm{E}$. Sealed vials were transported to the laboratory at $4{ }^{\circ} \mathrm{C}$ and stored at $-20^{\circ} \mathrm{C}$. The sediment sample was enriched for proteolytic bacteria in M5 medium containing 0.5\% tryptone and peptone (Dube et al., 2001). The medium was supplemented with trace element solution $(5 \mathrm{ml})$ and $10 \mathrm{ml}$ reducing solution $\left(11 \cdot 25 \mathrm{~g} \mathrm{Na}_{2} \mathrm{~S}\right.$ and $0 \cdot 125 \mathrm{~g}$ cysteic acid per $\left.10 \mathrm{ml}\right)$ per litre. The $\mathrm{pH}$ was adjusted to $7 \cdot 0$ by using $2 \mathrm{M} \mathrm{NaOH}$. Serum vials $(60 \mathrm{ml})$, each containing $30 \mathrm{ml}$ medium, were prepared anaerobically under a continuous flow of $\mathrm{N}_{2}$ and $\mathrm{H}_{2}(80: 20)$. The medium was inoculated with $2 \%$ sample and incubated at $10{ }^{\circ} \mathrm{C}$ for 1 week. Subculturing was done by transferring $5 \%$ inoculum to fresh bottles under similar conditions.

Tenfold serial dilutions of enriched cultures were prepared anaerobically in normal saline; $0 \cdot 1 \mathrm{ml}$ from each dilution step was spread on the surface of agar containing M5 medium with casein $(0.5 \%)$ in an anaerobic workstation (Don Whitley). Plates were incubated at $10{ }^{\circ} \mathrm{C}$ for 7 days; colonies showing zones of proteolysis were transferred to M5 broth. Several pure cultures were obtained, one of which was designated strain $\mathrm{AP} 15^{\mathrm{T}}$ and studied further. The cells were grown anaerobically in M5 broth that was devoid of casein but contained $0.5 \%$ each of tryptone and peptone. The effect of $\mathrm{pH}$ on growth and protease production was studied by growing cells in $30 \mathrm{ml} \mathrm{M} 5$ broth in $60 \mathrm{ml}$ serum vials. The $\mathrm{pH}$ of the media was adjusted between 5 and 13, at increments of $1 \mathrm{pH}$ unit, using $10 \mathrm{mM}$ buffers. The following buffers were used for different $\mathrm{pH}$ ranges: sodium acetate $(\mathrm{pH} 3 \cdot 0-5 \cdot 0)$, sodium citrate $(\mathrm{pH} 3 \cdot 0-5 \cdot 0)$, potassium phosphate $(\mathrm{pH} 6-8)$, Tris/HCl $(\mathrm{pH} 7 \cdot 0-9 \cdot 0)$, sodium

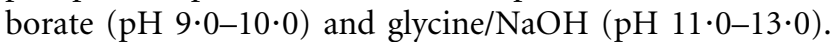
Vials were inoculated with $2 \%(\mathrm{v} / \mathrm{v})$ freshly grown culture $\left(\mathrm{OD}_{600}=0 \cdot 4\right)$ and incubation was carried out at $10^{\circ} \mathrm{C}$. Subsequently, the effect of $\mathrm{pH}$ was observed in greater detail (using increments of $0.5 \mathrm{pH}$ units) at $\mathrm{pH}$ values from 6 to 9 . Growth was observed by determining the $\mathrm{OD}_{600}$. Similarly, the effect of $\mathrm{NaCl}$ was evaluated by using $\mathrm{M} 5$ medium at various $\mathrm{NaCl}$ concentrations (1-15\%). Growth was monitored after 6 and 12 days incubation at $10^{\circ} \mathrm{C}$. For animal toxicity determinations, supernatants of early and late stationary phase cultures were titrated to ascertain the minimum lethal dose, using serial twofold dilutions made in gelatin diluent (Hall et al., 1985). An aliquot $(0.5 \mathrm{ml})$ of each dilution was inoculated intraperitoneally into each of six $20 \mathrm{~g}$ mice. The mice were observed for 4 days: flaccid paralysis and deaths were recorded. A Clostridium botulinum type E culture supernatant was used as the control in the mouse bioassay. Toxicity was not observed with the culture supernatant of strain $\mathrm{AP} 15^{\mathrm{T}}$.

The shape of the bacterium was determined by using light microscopy and scanning electron microscopy. Motility was examined by using the hanging drop technique (Pelczar et al., 1993). For scanning electron microscopy, cells were grown at $20^{\circ} \mathrm{C}$ for 6 days and collected by using low-speed centrifugation $\left(6000 \mathrm{~g}\right.$ for $5 \mathrm{~min}$ at $\left.4{ }^{\circ} \mathrm{C}\right)$. The pellet was

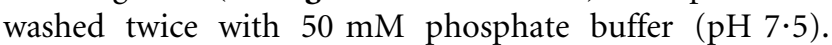
Glutaraldehyde (3\% final concentration) and osmium tetroxide ( $1 \%$ final concentration) were used for pre-fixation before serial dehydration in acetone. The cells were examined under a JEOL 840 scanning electron microscope at $5 \mathrm{kV}$ after gold coating of the mounted cells (JFC 1100 sputtercoating unit; JEOL).

For biochemical tests, the cultures were grown in M5 broth and tests were performed as described by Lanyi (1987) and Smibert \& Krieg (1994). Substrate-utilization studies were performed in basal medium containing complex substrates at $0.5 \%$ (trypticase, yeast extract, gelatin, peptone, carboxymethyl cellulose and Casamino acids), carbohydrates at $20 \mathrm{mM}$ (sucrose, fructose, arabinose, mannose, adonitol, mannitol, raffinose, glucose, lactose, melibiose, inositol, trehalose, maltose, dulcitol, xylan, arabitol, xylose, inulin, cellobiose, amygdalin, glycogen, galactose, rhamnose, ribose, sorbitol) and amino acids at $10 \mathrm{mM}$ (alanine, arginine, asparagine, aspartic acid, cysteine, glutamic acid, glutamine, glycine, histidine, 4-hydroxy-L-proline, isoleucine, lysine, methionine, threonine, tryptophan, tyrosine, valine, 2aminobutyric acid, ornithine, phenylalanine, serine, proline) as described by Mechichi et al. (1999). Tests were scored positive when a difference of $0 \cdot 1$ in the $\mathrm{OD}_{600 \mathrm{~nm}}$ was observed relative to cells grown in basal medium without carbon sources. Growth was also correlated with a fall in 
$\mathrm{pH}$ in the supernatant at full growth (as ascertained by the absence of any further increase in the $\left.\mathrm{OD}_{600}\right)$.

Chemicals were obtained from Sigma or Hi-Media and were of reagent grade. Tests for possible electron acceptors were carried out using basal media containing glucose, supplemented with $20 \mathrm{mM}$ sulfate, sulfite, thiosulfate, elemental sulfur or fumarate.

Quantitative analysis of glucose and its products in the culture media was carried out. Glucose was assayed with glucose oxidase (Merckotest; Merck). Volatile fatty acids and alcohols were determined by GC with a flame-ionization detector (Shimadzu) by using the method described by Mountfort \& Rhodes (1991). $\mathrm{H}_{2}, \mathrm{CO}_{2}$ and $\mathrm{H}_{2} \mathrm{~S}$ were measured using GC with a thermal conductivity detector.

The phenotypic properties of strain $\mathrm{AP}^{2} 5^{\mathrm{T}}$ are given in the species description. Characteristics useful for distinguishing strain $\mathrm{AP}^{\mathrm{T}} 5^{\mathrm{T}}$ from its closest relatives are listed in Table 1. Clostridium subterminale ATCC $25774^{\mathrm{T}}$ and Clostridium perfringens ATCC $13124^{\mathrm{T}}$ were used as controls in biochemical tests and in studies relating to morphology, motility, identification of fatty acids and DNA-DNA hybridization.

DNA was isolated according to the procedure of Marmur (1961), and the small-subunit rRNA gene was amplified using the two primers 16S1 (5'-GAGTTTGATCCTGGCTCA- $\left.3^{\prime}\right)$ and 16S2 (5'-CGGCTACCTTGTTACGACTT- $\left.3^{\prime}\right)$. The purified DNA product, which was approximately $1.5 \mathrm{~kb}$ in length, was sequenced using five forward primers and one reverse primer, as described previously (Reddy et al., 2000). The closest match to the deduced sequence was determined by a BLAST search (at http://www.ncbi.nlm.nih.gov). Pairwise evolutionary distances were computed using the DNADIST program with the Kimura two-parameter model (Kimura, 1980). Phylogenetic trees were constructed by using four tree-making algorithms: UPGMA, KITSCH, FITCH and DNAPARS from the PHYLIP package (Felsenstein, 1993). The stability among the clades of a phylogenetic tree was assessed by evaluating 1000 replicates of the dataset, and was analysed using the programs SEQBOOT, DNADIST, UPGMA and CONSENSE of the PHYLIP package.

Phylogenetic analysis based on 16S rRNA gene sequences indicated that $\mathrm{AP}^{\mathrm{T}} 5^{\mathrm{T}}$ was a member of the low-G $+\mathrm{C}$ content Gram-positive bacteria (Fig. 1) and was grouped within rRNA cluster I (Collins et al., 1994). The closest relatives of strain $\mathrm{AP}^{2} 5^{\mathrm{T}}$ were C. subterminale and Clostridium argentinense, which showed $99 \cdot 58$ and $99 \cdot 4 \%$ sequence similarity, respectively. DNA-DNA hybridization was performed by using the membrane filter method (Tourova \& Antonov, 1987), as described previously (Reddy et al., 2000; Shivaji et al., 1992). DNA of strain $\mathrm{AP}^{2} 5^{\mathrm{T}}$ exhibited only $55 \%$ binding with C. subterminale ATCC $25774^{\mathrm{T}}$ at the whole-genome level.

Cells were grown in M5 medium, and cellular fatty acid methyl esters were prepared according to the method of

Table 1. Differential characteristics of strain $\mathrm{AP} 15^{\top}$, C. subterminale and C. argentinense

All three taxa are negative for indole production and positive for $\mathrm{H}_{2} \mathrm{~S}$ production. Cells of all three taxa are rods. NR, Not reported.

\begin{tabular}{|c|c|c|c|}
\hline Characteristic & Strain $\mathrm{AP} 15^{\mathrm{T}}$ & C. subterminale & C. argentinense \\
\hline \multicolumn{4}{|l|}{ Growth characteristics } \\
\hline Temperature range $\left({ }^{\circ} \mathrm{C}\right)$ & $5-35$ & $25-45$ & $25-45$ \\
\hline pH optimum & $8 \cdot 0$ & $6 \cdot 0-6 \cdot 4$ & $6 \cdot 2-6 \cdot 3$ \\
\hline \multicolumn{4}{|l|}{ Biochemical characteristics } \\
\hline Aesculin hydrolysis & + & - & - \\
\hline $\mathrm{H}_{2}$ production ${ }^{*}$ & 1 & 4 & 4 \\
\hline$\beta$-Haemolysis & - & + & + \\
\hline Amino acids utilized & Arg, Leu, Ile, Cys, Glu, Ser & $\begin{array}{c}\text { Arg, Gly, Lys, Ser, Trp, } \\
\text { Phe, Tyr }\end{array}$ & Val, Leu, Lys \\
\hline Minor & $\mathrm{C}_{14: 0}, \mathrm{C}_{16: 1}, \mathrm{C}_{18: 0}, \mathrm{C}_{18: 1}$ & iso- $\mathrm{C}_{15: 0}, \mathrm{C}_{16: 7}, \mathrm{C}_{16: 9}$ & NR \\
\hline DNA G $+C$ content $(\mathrm{mol} \%)$ & 24 & 28 & 29 \\
\hline
\end{tabular}

${ }^{\star} \mathrm{H}_{2}$ production is given on a scale from ' 0 ' (no production) to ' $4+$ ' (abundant).

$\nmid$ PYG medium contains $0 \cdot 5 \%$ peptone, $2 \cdot 0 \%$ yeast extract and $0 \cdot 4 \%$ glucose. A, Acetate; $\mathrm{B}$, butyrate; F, formate; IB, isobutyrate; IV, isovalerate; $\mathrm{P}$, propionate; $\mathrm{PhA}$, phenylacetate. 


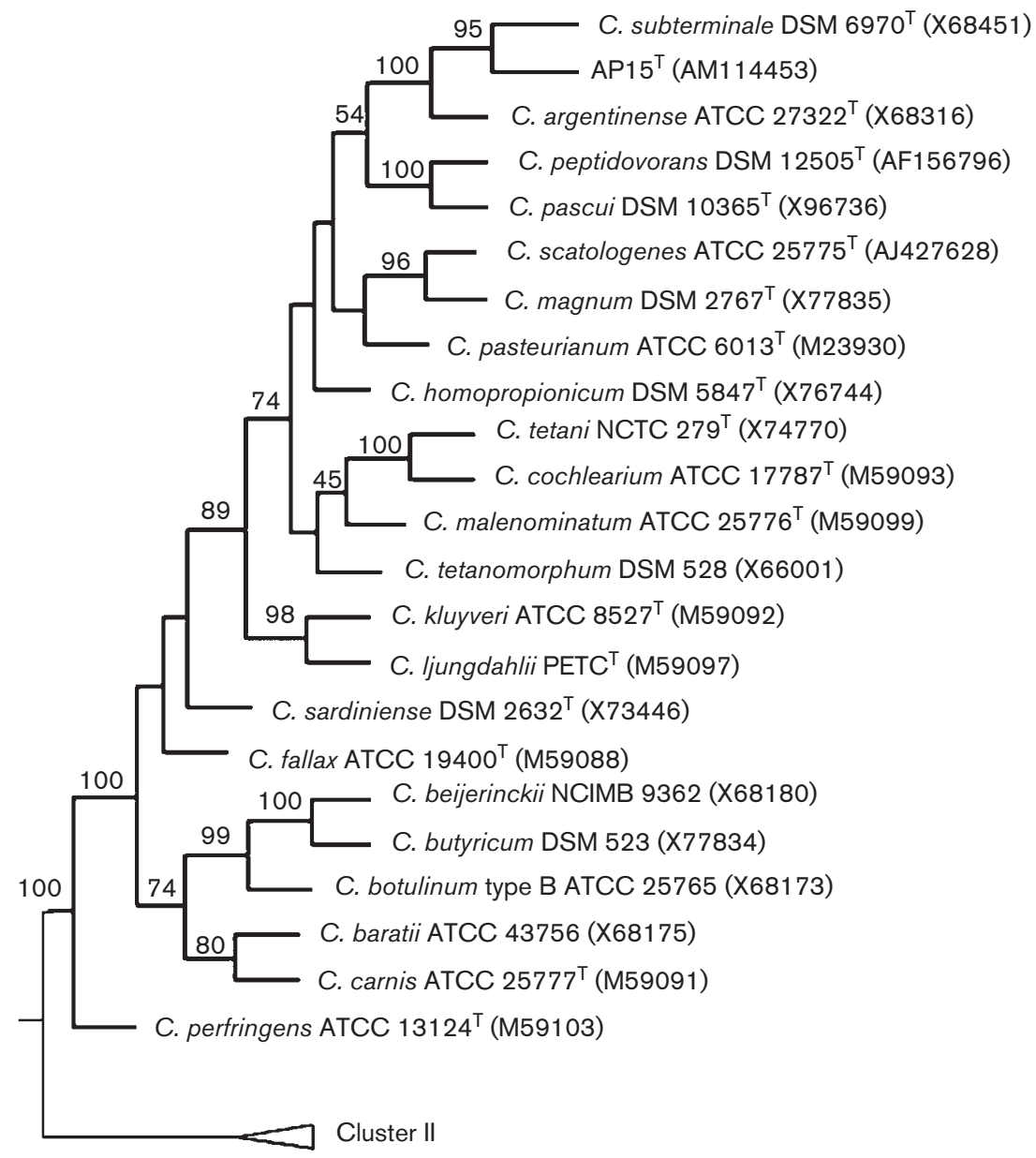

Fig. 1. UPGMA phenogram showing the phylogenetic relationships between strain $\mathrm{AP} 15^{\top}$ and related species of the genus Clostridium, based on 16S rRNA gene sequence analysis. Bootstrap values are given at the nodes. This is a consensus tree and the branch lengths in the phenogram are not to scale.
Sato \& Murata (1988). Methyl esters were analysed by GC/ MS (Thermo Finnigan Trace GC/MS). Cell walls were prepared and peptidoglycan was analysed by using the methods described by Schleifer \& Kandler (1972). Amino acids and peptides were separated and characterized by TLC on cellulose sheets. Phospholipids were analysed using silica-gel TLC as described by Komagata \& Suzuki (1987). Isolation of the DNA and determination of the DNA G + C content (mol\%) were performed by using the method of Reddy et al. (2000). The mean value from two independent experiments is given; the variation between the experiments was less than $2 \%$.

The predominant fatty acids in cells of strain $\mathrm{AP} 15^{\mathrm{T}}$ were $\mathrm{C}_{15: 0}, \mathrm{C}_{16: 0}$ and $\mathrm{C}_{17: 0}$, and there were only minor amounts of $\mathrm{C}_{14: 0}, \mathrm{C}_{16: 1}, \mathrm{C}_{18: 0}$ and $\mathrm{C}_{18: 1}$. The cells contained diphosphatidylglycerol as the major phospholipid, and mesodiaminopimelic acid was present in the cell wall. The DNA $\mathrm{G}+\mathrm{C}$ content was low $(24 \mathrm{~mol} \%)$.

A few examples of anaerobic bacteria isolated from various habitats of Antarctica (e.g. lake-water columns, sediments and samples from low-salinity ponds; Mountfort et al., 1997) have been described. Reports of true psychrophiles are scant, and, to the best of our knowledge, no proteolytic anaerobes from this icy continent have been described. This communication provides the first description of a proteolytic, psychrophilic Clostridium species from Antarctica.

Strain $\mathrm{AP}^{\mathrm{T}} 5^{\mathrm{T}}$ was assigned to the genus Clostridium on the basis of its main characteristics: it is fermentative, Grampositive, spore-forming, strictly anaerobic and does not utilize sulfate or nitrate as an electron acceptor (Cato et al., 1986). Phylogenetic analysis, based on 16S rRNA gene sequences, indicated that strain $\mathrm{AP} 15^{\mathrm{T}}$ is closely related to the genus Clostridium and is grouped within rRNA cluster I. Although strain $\mathrm{AP} 15^{\mathrm{T}}$ exhibited a maximum sequence similarity of $99.5 \%$ with C. subterminale at $16 \mathrm{~S}$ rRNA gene level, it showed only $55 \%$ overall DNA-DNA binding at the whole-genome level. Interestingly, the DNA G $+\mathrm{C}$ content was low $(24 \mathrm{~mol} \%)$ relative to that of C. subterminale and C. argentinense (28 and $29 \mathrm{~mol} \%$, respectively; Cato et al., 1986; Suen et al., 1988).

Furthermore, strain $\mathrm{AP} 15^{\mathrm{T}}$ differs from the type strains of both $C$. subterminale and $C$. argentinense with respect to its psychrophilic nature. The isolate tolerated up to $7 \cdot 5 \% \mathrm{NaCl}$ as against $6.5 \% \mathrm{NaCl}$ for both $C$. subterminale and $C$. argentinense (Cato et al., 1986). It grew optimally at $\mathrm{pH} 8 \cdot 0$, which is higher than the optimal $\mathrm{pH}$ values reported for $C$. 
subterminale $(\mathrm{pH} 6 \cdot 0-6 \cdot 4)$ and $C$. argentinense $(\mathrm{pH} 6 \cdot 2$ 6.3). The predominant fatty acids in cells of strain $\mathrm{AP} 5^{\mathrm{T}}$ are $\mathrm{C}_{15: 0}, \mathrm{C}_{16: 0}$ and $\mathrm{C}_{17: 0}$, and there are only minor amounts of $C_{14: 0}, C_{16: 1}, C_{18: 0}$ and $C_{18: 1}$. In the type strain of $C$. subterminale, the predominant fatty acids are $\mathrm{C}_{12: 0}, \mathrm{C}_{14: 0}$ and $\mathrm{C}_{16: 0}$, and there are only minor amounts of iso- $\mathrm{C}_{15: 0}$, $\mathrm{C}_{16: 7}$ and $\mathrm{C}_{16: 9}$ (Elsden et al., 1980). In addition to the above major differences, strain $\mathrm{AP} 15^{\mathrm{T}}$ differed from both C. subterminale and $C$. argentinense in that it could hydrolyse aesculin, did not produce $\beta$-haemolysis of sheep red blood cells and produced moderate amounts of $\mathrm{H}_{2}$ (Cato et al., 1986; Suen et al., 1988). It also differed from C. subterminale in that it was able to utilize leucine, isoleucine, cysteine and glutamate but not glycine, lysine, tryptophan, tyrosine or phenylalanine (Cato et al., 1986). Strain $\mathrm{AP}^{1} 5^{\mathrm{T}}$ did not utilize valine or isoleucine, unlike $C$. argentinense. The fermentation products of glucose are consistent with clostridial fermentation, but the stoichiometry differs from that of $C$. subterminale and $C$. argentinense in that it produces a large amount of propionate and a negligible amount of butyrate. Thus, these differentiating characteristics support novel species status for strain $\mathrm{AP} 15^{\mathrm{T}}$ within the genus Clostridium, and we propose the name Clostridium schirmacherense sp. nov.

\section{Description of Clostridium schirmacherense sp. nov.}

Clostridium schirmacherense (schir.ma.cher.en'se. N.L. neut. adj. schirmacherense pertaining to Schirmacher Oasis in Antarctica).

Cells are motile, Gram-positive rods $(2-4 \times 0 \cdot 5-0 \cdot 7 \mu \mathrm{m})$ that form spores. Spores are subterminal and distend the cell. Strictly anaerobic and chemo-organotrophic. Grows at temperatures in the range $5-35^{\circ} \mathrm{C}$ and produces maximum cell mass at $5-10^{\circ} \mathrm{C}$. The $\mathrm{pH}$ range for growth is between 6 and 9 , with an optimum at $\mathrm{pH} 8 \cdot 0 . \mathrm{NaCl}$ is not required for growth but is tolerated up to a concentration of $7 \cdot 5 \%$ (Table 1). Hydrolyses aesculin, gelatin and casein, produces $\mathrm{H}_{2} \mathrm{~S}$ but does not reduce nitrate to nitrite. Negative for catalase, oxidase, lipase, indole production and $\beta$-haemolysis. Utilizes raffinose, glucose, adonitol, rhamnose and ribose but not sucrose, arabinose, mannose, mannitol, lactose, inositol, trehalose, maltose, dulcitol, xylan, arabitol, xylose, inulin, amygdalin, glycogen, galactose or sorbitol. Complex substrates such as yeast extract, Casamino acids, peptone and gelatin are also fermented. Some amino acids, including arginine, serine, leucine, isoleucine, cysteine and glutamate, are utilized whereas asparagine, proline, glutamine, aspartate, glycine, lysine, methionine, threonine, tryptophan, tyrosine, valine, 2-aminobutyric acid, ornithine and phenylalanine are not utilized. Sulfite and thiosulfate are reduced but sulfate, elemental sulfur and fumarate are not reduced. The major fermentation end-products are as follows: acetate, propionate, $\mathrm{H}_{2}$ and $\mathrm{CO}_{2}$ from glutamate; acetate and butyrate from isoleucine; acetate, propionate, $\mathrm{H}_{2}$ and $\mathrm{CO}_{2}$ from cysteine; formate, acetate and propionate from arginine; acetate, propionate, $\mathrm{H}_{2}$ and $\mathrm{CO}_{2}$ from leucine; and acetate, isobutyrate and butyrate from serine. Details of the amino acid fermentation products are available as supplementary data (Supplementary Table S1) in IJSEM Online. Glucose is fermented to formate, acetate, propionate, butyrate, isovalerate, $\mathrm{H}_{2}$ and $\mathrm{CO}_{2}$ (Supplementary Table $\mathrm{S} 2$ in IJSEM Online). Contains diphosphatidylglycerol as the major phospholipids, and meso-diaminopimelic acid is present in the cell wall. The major cellular fatty acids are $\mathrm{C}_{15: 0}, \mathrm{C}_{16: 0}$ and $\mathrm{C}_{17: 0}$. The $\mathrm{G}+\mathrm{C}$ content of the DNA is $24 \mathrm{~mol} \%$.

The type strain, $\operatorname{AP}^{2} 5^{\mathrm{T}}\left(=\mathrm{DSM} 17394^{\mathrm{T}}=\mathrm{JCM} 13289^{\mathrm{T}}\right)$, was isolated from lake sediments of Schirmacher Oasis, Antarctica.

\section{Acknowledgements}

We thank K. Sekhar (Director, DRDE, Gwalior, India) for providing all of the facilities and support required for this study.

\section{References}

Alam, S. I., Singh, L., Dube, S., Reddy, G. S. N. \& Shivaji, S. (2003). Psychrophilic Planococcus maitriensis sp. nov. from Antarctica. Syst Appl Microbiol 26, 505-510.

Attwood, G. T., Reilly, K. \& Patel, B. K. C. (1996). Clostridium proteoclasticum sp. nov., a novel proteolytic bacterium from the bovine rumen. Int J Syst Bacteriol 46, 753-758.

Broda, D. M., Saul, D. J., Lawson, P. A., Bell, R. G. \& Musgrave, D. R. (2000a). Clostridium gasigenes sp. nov., a psychrophile causing spoilage of vacuum-packed meat. Int J Syst Evol Microbiol 50, 107-118.

Broda, D. M., Saul, D. J., Bell, R. G. \& Musgrave, D. R. (2000b). Clostridium algidixylanolyticum sp. nov., a psychrotolerant, xylandegrading, spore-forming bacterium. Int J Syst Evol Microbiol 50, 623-631.

Cato, E. P., George, W. L. \& Finegold, S. M. (1986). Genus Clostridium Prazmowski 1880, 23 ${ }^{\mathrm{AL}}$. In Bergey's Manual of Systematic Bacteriology, vol. 2, pp. 1141-1200. Edited by P. H. A. Sneath, N. S. Mair, M. E. Sharpe \& J. G. Holt. Baltimore: William \& Wilkins.

Collins, M. D., Lawson, P. A., Willems, A., Cordoba, J. J., FernandezGarayzabal, J., Garcia, P., Cai, J., Hippe, H. \& Farrow, J. A. E. (1994). The phylogeny of the genus Clostridium: proposal of five new genera and eleven new species combinations. Int $J$ Syst Bacteriol 44, 812-826.

Dixit, A., Dhaked, R. K., Alam, S. I. \& Singh, L. (2005). Characterization of Clostridium sp. RKD producing botulinum-like neurotoxin. Syst Appl Microbiol 28, 405-414.

Dube, S., Singh, L. \& Alam, S. I. (2001). Proteolytic anaerobic bacteria from lake sediments of Antarctica. Enzyme Microb Technol 28, 114-121.

Elsden, S. R., Hilton, M. G., Parsley, K. R. \& Self, R. (1980). The lipid fatty acids of proteolytic clostridia. J Gen Microbiol 129, 1075-1081.

Engle, M., Li, Y., Rainey, F., DeBlois, S., Mai, V., Reichert, A., Mayer, F., Messner, P. \& Wiegel, J. (1996). Thermobrachium celere gen. nov., sp. nov., a rapidly growing thermophilic, alkalitolerant, and proteolytic obligate anaerobe. Int J Syst Bacteriol 46, 1025-1033.

Felsenstein, J. (1993). PHYLIP (phylogeny inference package), version 3.5c. Distributed by the author. Department of Genome Sciences, University of Washington, Seattle, USA.

Franzmann, P. D. \& Dobson, S. J. (1992). Cell wall-less, free-living spirochetes in Antarctica. FEMS Microbiol Lett 97, 289-292. 
Franzmann, P. D. \& Rohde, M. (1991). An obligately anaerobic, coiled bacterium from Ace Lake, Antarctica. J Gen Microbiol 137, 2191-2196.

Franzmann, P. D., Roberts, N. J., Mancuso, C. A., Burton, H. R. \& McMeekin, T. A. (1991). Methane production in meromictic Ace Lake, Antarctica. Hydrobiologia 210, 191-201.

Hall, J. D., McCroskey, L. M., Pincomb, B. J. \& Hatheway, C. L. (1985). Isolation of an organism resembling Clostridium baratii which produces type $\mathrm{F}$ botulinal toxin from an infant with botulism. J Clin Microbiol 21, 654-655.

Johnson, R. M. \& Bellinoff, R. D. (1981). A taxonomic study of a dominant coryneform bacterial type found in Antarctic soils. Antarct Res Ser 30, 169-184.

Johnson, R. M., Inai, M. \& McCarty, S. (1981). Characteristics of cold desert Antarctic coryneform bacteria. J Ariz-Nev Acad Sci 16, 51-60.

Kimura, M. (1980). Simple method for estimating evolutionary rates of base substitutions through comparative studies of nucleotide sequences. J Mol Evol 16, 111-120.

Komagata, K. \& Suzuki, K. (1987). Lipid and cell wall analysis in bacterial systematics. Methods Microbiol 19, 161-207.

Lanyi, B. (1987). Classical and rapid identification methods for medically important bacteria. Methods Microbiol 19, 1-67.

Madden, J. M., Siegel, S. K. \& Johnson, R. M. (1979). Taxonomy of some Antarctic Bacillus and Corynebacterium species. Antarct Res Ser 30, 77-103.

Marmur, J. (1961). Procedure for the isolation of deoxyribonucleic acid from microorganisms. J Mol Biol 3, 208-218.

Mechichi, T., Labat, M., Patel, B. K. C., Woo, T. H. S., Thomas, P. \& Garcia, J. L. (1999). Clostridium methoxybenzovorans sp. nov., a new aromatic $o$-demethylating homoacetogen from an olive mill wastewater treatment digester. Int J Syst Bacteriol 49, 1201-1209.

Miller, K. J. \& Leschine, S. B. (1984). A halotolerant Planococcus from Antarctic dry valley soil. Curr Microbiol 11, 205-210.

Mountfort, D. O. \& Rhodes, L. L. (1991). Anaerobic growth and fermentation characteristics of Paecilomyces lilacinus isolated from mullet gut. Appl Environ Microbiol 57, 1963-1968.
Mountfort, D. O., Rainey, F. A., Burghardt, J., Kaspar, H. F. \& Stackebrandt, E. (1997). Clostridium vincentii sp. nov., a new obligately anaerobic, saccharolytic, psychrophilic bacterium isolated from low-salinity pond sediment of the McMurdo Ice Shelf, Antarctica. Arch Microbiol 167, 54-60.

Pelczar, M. J., Jr, Chan, E. C. S. \& Krieg, N. R. (1993). Microbiology: Concepts and Applications. New York: McGraw-Hill.

Reddy, G. S. N., Aggarwal, R. K., Matsumoto, G. I. \& Shivaji, S. (2000). Arthrobacter flavus sp. nov., a psychrophilic bacterium isolated from a pond in McMurdo Dry Valley, Antarctica. Int J Syst Evol Microbiol 50, 1553-1561.

Sato, N. S. \& Murata, N. (1988). Membrane lipids. Methods Enzymol 167, 251-259.

Schleifer, K. H. \& Kandler, O. (1972). Peptidoglycan types of bacterial cell walls and their taxonomic implications. Bacteriol Rev 36, 407-477.

Shivaji, S., Rao, N. S., Saisree, L., Reddy, G. S. N., Kumar, G. S. \& Bhargava, P. M. (1989). Isolates of Arthrobacter from the soils of Schirmacher Oasis, Antarctica. Polar Biol 10, 225-229.

Shivaji, S., Ray, M. K., Rao, N. S., Saisree, L., Jagannadham, M. V., Kumar, G. S., Reddy, G. S. N. \& Bhargava, P. M. (1992). Sphingobacterium antarcticus sp. nov., a psychrotrophic bacterium from the soils of Schirmacher Oasis, Antarctica. Int J Syst Bacteriol 42, 102-106.

Smibert, R. M. \& Krieg, N. R. (1994). Phenotypic characterization. In Methods for General and Molecular Bacteriology, pp. 607-654. Edited by P. Gerhardt. Washington, DC: American Society for Microbiology.

Suen, J. C., Hatheway, C. L., Steigerwalt, A. G. \& Brenner, D. J. (1988). Clostridium argentinense sp. nov.: a genetically homogeneous group composed of all strains of Clostridium botulinum toxin type $\mathrm{G}$ and some nontoxigenic strains previously identified as Clostridium subterminale or Clostridium hastiforme. Int J Syst Bacteriol 38, 375-381.

Toda, Y., Saiki, T., Uozomi, T. \& Beppu, T. (1988). Isolation and characterization of a protease-producing, thermophilic, anaerobic bacterium, Thermobacteroides leptospartum sp. nov. Agric Biol Chem 52, 1339-1344.

Tourova, T. P. \& Antonov, A. S. (1987). Identification of microorganisms by rapid DNA-DNA hybridization. Methods Microbiol 19, 333-355. 